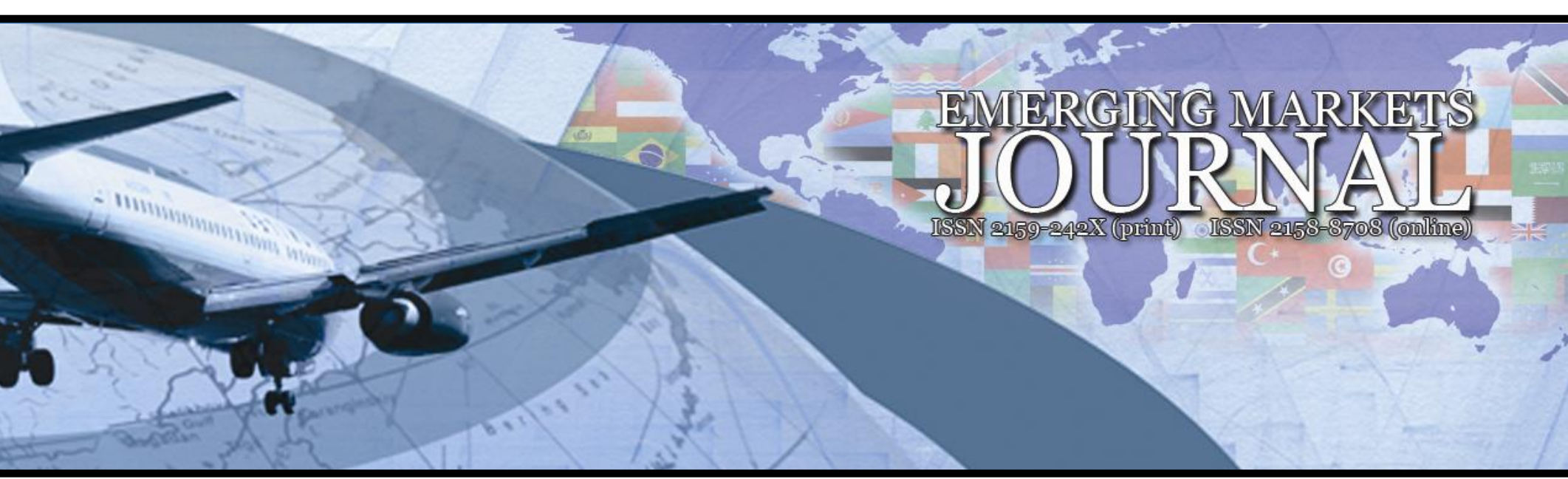

\title{
STRATEGIES FOR COMPETITIVE ADVANTAGE IN ELECTRONIC COMMERCE
}

\author{
Siamak Azadi \\ Universiteti Politeknik i Tiranes | e-mail: irmitash@yahoo.com
}

Volume 1 (2011) | ISSN 2158-8708 (online) | DOI 10.5195/emaj.2011.13 | http://emaj.pitt.edu

\section{Abstract}

Despite rapid and sustained development of electronic commerce, many companies doing e-business are still in the investment and brand-building phase and have yet to show a profit. However, as e-businesses shift their focus from building a customer base to increasing revenue growth and profitability, they should reevaluate their current business strategies, if any, and develop strategies that provide a clear path to profitability. This study uses McCarthy's four marketing mix model and Porter's five competitive forces model to identify strategies for Internet companies that respond to the five competitive forces and thereby achieve a competitive advantage. The study provides significant new insights into the development and implementation of e-business strategies that contribute to increased profit.

Keywords: E-Business, Business Strategy, Marketing Mix, Competitive Forces, Profitability, Competitive Advantage

\section{(c) BY-NC-ND}

This work is licensed under a Creative Commons Attribution-Noncommercial-No Derivative Works 3.0 United States License.

\section{ULLS D-Sonle}

This journal is published by the University Library System of the University of Pittsburgh as part of its $\underline{D}$-Scribe Digital Publishing Program, and is cosponsored by the University of Pittsburgh Press 


\section{Strategies For Competitive Advantage In Electronic Commerce}

\author{
Siamak Azadi
}

\section{Introduction}

E-commerce is fundamentally changing the economy and the way business is conducted. Ecommerce forces companies to find new ways to expand the markets in which they compete, to attract and retain customers by tailoring products and services to their needs, and to restructure their business processes to deliver products and services more efficiently and effectively. However, despite rapid and sustained development of ecommerce, many companies doing e-business are still in the investment and brand-building phase and have yet to make a profit (Zwass 1998). Many e-businesses (or Internet companies) have focused on the visual attractiveness and ease of use of their Web sites as the primary method of increasing their customer base.

However, as e-businesses shift their focus from building a customer base to increasing revenue growth and profitability, they should re-evaluate their current business strategies, if any, and develop strategies that provide a clear path to profitability.

This study uses McCarthy's (1960) four marketing mix model and Porter's $(1980,1985)$ five competitive forces model to identify strategies for Internet companies (or dot.coms) that respond to the five competitive forces and thereby achieve a competitive advantage. The overall goal is to provide significant new insights into the development and implementation of e-business strategies that contribute to increased profit.

This research is organized around two questions:
1) What impact does the Internet have on McCarthy's four marketing mix (product, price, promotion, and

place) and Porter's competitive forces (the threat of new entrants, rivalry among existing firms, the threat of substitutes, the bargaining power of suppliers, and the bargaining power of buyers)?

2) What strategies can be derived from the four marketing mix that will affect the five competitive forces and thereby bring a competitive advantage to e-businesses?

\section{Global crisis effects}

The world economy is mired in the worst financial crisis since the Great Depression. What first appeared as a sub-prime mortgage crack in the United States housing market during the summer of 2007 began widening during 2008 into deeper fissures across the global financial landscape and ended with the collapse of major banking institutions, precipitous falls on stock markets across the world and a credit freeze. These financial shockwaves have now triggered a full-fledged economic crisis, with most advanced countries already in recession and the outlook for emerging and other developing economies deteriorating rapidly, including those with a recent history of strong economic performance.

The crisis has already had a severe impact on global commodity markets with far-reaching implications for the prospects of the developing world at large. Commodity prices have been highly volatile during 2008. Most prices surged in the first half of 2008, continuing a trend that had begun in 2003. Trends in world market prices reversed sharply from mid-2008, however. Oil prices have plummeted by more than 60 per cent from their peak levels of July to November. The prices of other commodities, including basic grains, also declined significantly. In the outlook, most of these 
prices are expected to even out further along with the moderation in global demand.

Growth of world trade decelerated to 4.3 per cent in early 2008, down from 6.4 per cent in 2007, owing mainly to a decline in imports by the United States. United States imports, which account for about 15 per cent of the world total, have registered a decline in every quarter since the fourth quarter of 2007 and dropped as steeply as 7 per cent in the second quarter of 2008. Growth in the volume of world trade had dropped to about 3 per cent by September 2008, to about one third of the rate of growth a year earlier. In the outlook, global trade is expected to weaken further in 2009. Owing to their limited exposure to the mortgage market derivatives that brought down major banks in the United States and Europe, financial systems in most developing countries initially seemed shielded from any direct impact from the international financial crisis.

Growing risks have emerged through other channels, however, as investors have started to pull back resources from emerging market economies and other developing countries as part of the deleveraging process of financial institutions in the developed countries.

Unlike in recent years when the spread varied significantly across regions and countries to indicate investor discrimination among countryspecific risks, the latest surge has been uniform, suggesting that contagion and aversion to investing in emerging markets has taken hold among investors. Spreads are expected to remain high in 2009, as the strains in global credit markets linger and also as capital flows to emerging market economies are projected to drop further.

Our society is facing a financial crisis, an economic crisis, and as recent research is increasingly showing, a humanitarian crisis. Recession has hit the entire world. Wherever we go everybody is talking about it and each and every trade is affected by it.
The declining quality of work opportunities, barriers to employment, exploitation and the failure of income support programs to protect families from debilitating poverty impact everyone. While the country's increasing rates of incarceration impact communities of color disproportionately, our willingness to punish formerly imprisoned people indefinitely affects all of our lives negatively, as we make it impossible for them to contribute to our common wellbeing. The marginalization of poor immigrants of color helps to pull down labor standards for everyone, making work increasingly precarious for all workers. In the larger economic picture, the creation of populations who are unemployed and underemployed at far higher rates than the societal norm, and who remain locked out of stable employment, contributes to the country's overall levels of inequality. High levels of inequality are predictive of the overall lack of a robust national economy. Removing barriers to equal employment for whole populations of people is one very obvious way to begin dismantling inequality in employment and help rebuild the national economy.

In this recession, poverty could grow massively. As the economic crisis continues, deep recession could push $25 \%$ of middle-class families into more serious financial distress. The danger is higher for families of color, with $33 \%$ of Blacks and $41 \%$ of Latinos at risk of falling out of the middle class and into poverty (J. Huezo et al. 2009) According to the Bureau of Labor Statistics, eight of the 10 occupations projected to generate the most jobs by 2016 are low-wage jobs in the service sector (A. Bernhardt and C. Owens, 2009). These are precarious jobs that will make more and more workers extremely vulnerable to even small economic fluctuations.

While developed countries are experiencing some of the sharpest economic contractions, households in developing countries are much more vulnerable, and likely to experience acute negative consequences, both in the short- and long-term. (Justin Yifu Lin, 2009) 
Declining growth rates combined with high levels of initial poverty leave many households in developing countries highly exposed to the crisis. Vulnerability is heightened if, at the same time, governments are constrained in cushioning the impacts due to limited institutional capacity and fiscal resources.

When the financial crisis first broke, it was thought that developing countries in general would not be affected because their financial sector was not fully integrated in the global financial system. But now as the crisis has

entered the second stage and problems in the real sector have emerged, it has become clear that developing countries will also be seriously affected by the downturn.

Between 2002 and 2007, these countries grew rapidly because of global trade expansion and the large inflows of private capital, including foreign direct investment (FDI), the increase in remittances and the surge in commodity prices. In fact, in 2007, private capital flows to the developing countries amounted to $\$ 1.2$ trillion, a six-fold increase compared to the beginning of the decade, thanks in part to the rise in FDI which responded to the higher export earnings of the resource-rich developing countries. These higher earnings, in turn, were made possible by higher world commodity prices. Also, workers' remittances expanded three times to $\$ 328$ billion over the same period. Now, with the crisis taking its toll, it is estimated that total FDI and private capital flows will decline from $\$ 1.2$ trillion in 2007 to $\$ 363$ billion this year. As a result of declining exports and reduced capital inflows, the developing countries may encounter a financing gap of between $\$ 352$ billion to $\$ 635$ billion. Moreover, remittances are likely to fall by 7.3 percent in 2009 to the level of $\$ 305$ billion.

The GDP growth rate in developing countries in 2009 is forecast to drop to 1.2 percent, a sharp decline from 8.1 percent of growth rate in 2007 and 5.9 percent growth rate in 2008. This decline alone will cause more than 30 million workers to lose their jobs according to the United Nations International Labour Organization, and of course, poverty will rise. In fact, if we don't do anything, this may just be the start of the worst scenario.

New estimates for 2009 suggest that lower economic growth rates would trap 53 million more people in poverty, those living on less than $\$ 1.25 \mathrm{a}$ day than was expected prior to the crisis. If the $\$ 2$ a-day poverty line is used, 65 million will stay trapped. If the recession protracts, more and more people will fail to get out of poverty.

As Robert Zoellick, World Bank Group President, has said, "The global economic crisis threatens to become a human crisis in many developing countries unless they can take targeted measures to protect vulnerable people in their communities."

Critical to protecting households in countries exposed to the crisis will be the ability of governments to cope with the fallout of the downturn: to finance programs that create jobs, ensure the delivery of core services and infrastructure, and provide safety nets. Yet, only one-third of the exposed countries have the fiscal capacity (i.e., ability to expand fiscal deficits) to render significant countercyclical spending. In countries with limited fiscal capacity it is imperative that assistance be provided via grants and concessional financing wherever possible. Moreover, one-third of the countries with a reasonable amount of fiscal capacity are aid dependent, and will also require external support to finance increased spending.

\section{The crisis effects in South-Eastern Europe}

All economies in South-eastern Europe continued to grow at relatively robust rates in the order of 5 per cent or higher in 2008, with the exception of Croatia which had 3.8 per cent. Growth in 2008 continued to be largely driven by domestic demand, underpinned by rising real 
wages, strong FDI inflows and domestic credit expansion. However, in the course of the year, and with the escalation of the global financial crisis, these growth factors started to lose steam and will weaken further in 2009. Hence, a further moderation in the pace of growth to about 4.5 per cent for the region as a whole is expected in the baseline scenario for 2009 , down from 5.2 per cent in 2008 .

Inflation accelerated in South-eastern Europe in the first half of 2008, driven by surging world food and energy prices, strong domestic demand and rising real wages. The acceleration was quite pronounced in Bosnia and Herzegovina, Croatia, Serbia and the Former Yugoslav Republic of Macedonia. However, during the second half of the year, inflationary pressures weakened as world commodity prices started to fall from their highs and domestic inflationary pressures subsided. Given the overall domestic and global macroeconomic prospects, this trend is likely to gain further ground in 2009 .

Employment conditions improved in all South-eastern European economies along with the continued dynamic economic performance in much of 2008. Nonetheless, unemployment rates remain very high (about 16 per cent on average); only Croatia has a single-digit rate of unemployment. Nevertheless, positive labor market developments are expected to continue in 2009 as a result of new investments in production capacity and the implementation of infrastructure projects. In Croatia, though, the rate of unemployment may increase in response to weaker performance of the tourism industry.

The general government budgets in most South-eastern European economies have become more balanced and were fortified by higher tax revenue following strong economic growth in recent years. There was some fiscal loosening in a number of countries in 2008, in part because of their electoral cycle. Fiscal deficits are expected to widen as a result of the economic slowdown and anticipated expected fiscal responses in 2009, but larger deficits do not pose an immediate threat to macroeconomic stability.

In contrast, there was a notable tightening of monetary policy in 2008, partly in response to rising inflationary pressures. Central banks increased their policy rates in Albania, Serbia (in stages) and the Former Yugoslav Republic of Macedonia, while mandatory reserve requirements were increased in Bosnia and Herzegovina and Croatia. The domestic monetary tightening was coupled with deteriorating conditions of access to international financial markets. The rising cost of credit is likely to further dampen economic activity in the region.

Against the backdrop of strong domestic demand and weakening import demand in the important European markets, imports by Southeastern European economies generally outpaced their exports in 2008. As a result, both trade and current-account deficits continued to widen in all countries and, in a number of cases, have reached alarming proportions. Financing these deficits up until the 2008 crisis did not pose a problem, but financing conditions have been changing for the worse, forcing a downward adjustment in domestic demand. The restraining effect of unfavorable financing conditions is likely to increase further in 2009 and the deficits may decline somewhat in the short run.

\section{The poor as victims or as resilient and important consumers?}

Coming on the heels of the food and energy security crises, the global financial crisis will most likely substantially set back progress towards poverty reduction and the Millennium Development Goals. The tightening of access to credit and weaker growth will cut into public revenues and limit the ability of developing country Governments to make the necessary investments to 
meet education, health and other human development goals.

Unless adequate social safety nets are in place, the poor will no doubt be hit the hardest. An estimated 125 million people in developing countries were already driven into extreme poverty because of the surge in global food prices since 2006.

In the global economy, lasting competitive value is no longer assured by natural resources, human talent, or even core competencies. In these areas, the world is indeed flat. Sustaining innovative solutions and beating the competition is about tapping software and digital applications to wire customer knowledge into the core systems of the firm and measure customer behavior through smart analytics. And this can be done at lower costs and in faster time frames than many understand. The rise of global supply chains in Asia, Eastern Europe and the West are highly competitive, fearless, and bubbling with new approaches driven by the young and ambitious upstarts of the next business generation. Coming to terms with the implications of this transformation is both urgent and inevitable for the survival of businesses (C.K Prahalad and M.S Krishnan, 2008). CEOs, senior executives, and managers of every level face an imperative to understand that to form strategy and execute it they must renew their knowledge of business processes, information technology, and data analysis. To win in the competitive landscape defined by creating one consumer experience at a time, decision makers must develop a "whole new mind" for understanding their global supply, logistics and communications networks.

The focus of young people and young professionals on sites such as My Space, YouTube, and Facebook suggest that a whole generation of consumers are growing up expecting to be treated as unique individuals, and will have the skills and the propensity to engage in a market place defined by customer co-creation. Value for them is not about traditional ideas of quality. That is a given. They want to be involved in shaping their own experiences.

Similarly, the imperatives of access to talent, speed, and cost will drive most firms towards this new global resourcing. By forging the 'always on' network, firms can engage customers and employees emotionally and intellectually in the mission of the firm, minute by minute, day by day.

As Prahalad writes: "From cement to jet engines, from children's toys to delivery of parcels to your home or office by UPS, all industries are going through this transformation. This transformation is not a choice." (C.K. Prahalad, 2008)

While there is a strong demand among the urban poor for better services and quality goods, as well as a demonstrated ability to pay for those services and goods, the failure of the private sector to provide adequate services and goods is in fact a contributor to poverty. Because of the deliberate exclusion of the urban poor from mainstream urban market systems, they live in very high cost economies. For instance, slum dwellers without access to municipal water pay 4 to 100 times as much as their middle and upper class counterparts. They also pay $30 \%$ to $50 \%$ more for food items that are sold in small unit packages.

The availability, accessibility and affordability of private sector goods and services are bound to change the situation of the urban poor and in turn address some of the challenges facing urban centers today. By expanding the global market system to include the urban poor would provide new markets for the private sector and at the same time create opportunities for poor communities. For example, the wireless telecommunication industry in Africa and Asia has been able to create a sustainable win-win situation for the private sector and the urban poor. Mobile communication allows an incredible whole range of new ways to conduct business for the small slumbased entrepreneurs. This industry has created systems and channels that have increased 
availability of affordable mobile phone service for the poor without creating cost structures that translate to higher prices for the poor. Instead it has opened and created new business possibilities for the poor through access to technology, which a few years back was considered the prerogative of the middle and upper class (Auclair C, 2008).

\section{Bottom of the pyramid}

In 1932, the phrase "bottom of the pyramid" was used by former United States President Franklin D. Roosevelt in a radio address to his country that was in the midst of the Great Depression. He said, "These unhappy times call for the building of plans that rest upon the forgotten, the unorganized but the indispensable units of economic power (plans) that put their faith once more in the forgotten man at the bottom of the economic pyramid". It is almost an ominous coincidence that 80 years hence, we are also in the midst, although hopefully at the tail end, of a global crisis. It is apparent that President Roosevelt's statement is as relevant for us today, as it was then.
Indeed, it is in adequately and appropriately serving and strengthening the sectors that we will be able to build a solid base for economic growth and development.

"If we stop thinking of the poor as victims or as a burden and start recognizing them as resilient and kreative entrepreneurs and valueconscious consumers, a whole new world of opportunity will open up". (C.K. Prahalad, 2008)

Popularized by C.K. Prahalad, the Bottom of the Pyramid concept which contends that poor people should be seen as potentially profitable customers rather than mere charity cases has caught on fast in the past few years. While some organizations have taken notice and reaped benefits, the bottom of the pyramid has been largely ignored by most. Multinationals and even local companies are yet to be convinced there is a large enough profitable market. For long time the MNC have the idea that the poor cannot be the segment who they can be focus. The reasons are given to the table ( $\mathrm{C}$. K. Prahalad and Stuart Hart, 2002).

\begin{tabular}{|c|c|}
\hline Assumption & Implication \\
\hline $\begin{array}{c}\text { The poor are not our target customers; they } \\
\text { cannot afford our products or services. }\end{array}$ & $\begin{array}{c}\text { Our cost structure is a given; with our cost structure, we cannot } \\
\text { serve the BOP market. }\end{array}$ \\
\hline $\begin{array}{c}\text { The poor do not have use for products sold in } \\
\text { developed countries }\end{array}$ & $\begin{array}{c}\text { We are committed to a form over functionality. The poor might } \\
\text { need sanitation, but can't afford detergents in formats we offer. } \\
\text { Therefore, there is no market in the BOP. }\end{array}$ \\
\hline $\begin{array}{c}\text { Only developed countries appreciate and pay for } \\
\text { technological innovations. }\end{array}$ & $\begin{array}{c}\text { The BOP does not need advanced technology solutions; they } \\
\text { will not pay for them. Therefore, the BOP cannot be a source of } \\
\text { innovations }\end{array}$ \\
\hline $\begin{array}{c}\text { The BOP market is not critical for long-term } \\
\text { growth and vitality of MNCs }\end{array}$ & $\begin{array}{c}\text { BOP markets are at best an attractive distraction. } \\
\text { Intellectual excitement is in developed markets; it } \\
\text { is very hard to recruit managers for BOP markets }\end{array}$ \\
\hline
\end{tabular}

1. The Dominant Logic of MNCs as It Relates to BOP 
The numbers are clearly against the views of such companies. More than half the world's population lives on less than US\$ 2 a day. There is striking disparity between the rich and the poor with over $76.6 \%$ of the private consumptions made by 2 richest deciles of the world's population.

The distribution of wealth and the capacity to generate incomes in the world can be captured in the form of an economic pyramid. At the top of the pyramid are the wealthy, with numerous opportunities for generating high levels of income. More than 4 billion people live at the BOP on less than $\$ 2$ per day.

For more than 50 years, the World Bank, donor nations, various aid agencies, national governments, and, lately, civil society organizations have all fought the good fight, but have not eradicated poverty.

While various quarters shudder at the thought of the three crises mentioned there also laid limitless opportunities for enterprises, governments and entrepreneurs. The financial crisis maybe associated with closures and companies going bankrupt, but it must be kept in mind that some of the best known companies have thrived while some were born during such times. Companies should be tough in anticipation of tough times. They should seize the downturn opportunities gear-up for the upturn.

The BOP three pillar principles posses the following questions to the private sector:

- Are the goods and services in the market available to the poor?

- How accessible and at the disposal of the poor are these goods and services?

- Can the poor afford what is being proposed to them by the markets?
If managers do not recognize this trend and get organized to compete in this new environment, they are likely to be left behind. Businesses will need to ceaselessly improve flexibility and efficiency and transparency in all IT and customerfacing processes. Ultimately, the race for the future will be won by those who deliver a unique customer experience at the lowest cost.

The crisis saw failure and closures of thousands of businesses worldwide, record unemployment, declines in consumer wealth estimated in the trillions of U.S. dollars, substantial financial commitments incurred by governments, and most notably significant decline in economic activity around the globe. Now many economists, political leaders, bankers and other market commentators are jubilantly declaring the worst is over and everything is ok again. These same analysts who were oblivious to the looming financial debacle are ignoring evidence which corroborate that this marks only the beginning of larger impending global crisis.

Beyond the global recession, the world also needs to brace for more crises in the coming years. MTI Consulting' CEO Hilmy Cader states "We are not out of the woods yet-the worst is yet to come! We still need to deal with the impact and aftershocks of the financial meltdown and the long term changes it has brought about. Also the world, particularly the emerging and developing nations should be on guard to face a greater impacting Eco Credit Crisis and Bottom of the Pyramid Crisis" (Hilmy Cader, 2009).

Economies and enterprises should also be cautious of long term changes and implications that maybe brought about by the crisis. Consumer's tendency to save and avoid large debt will become more popular leading to long term drop in consumption. Government spending will also reduce in the long term which coupled with reduced private consumption will slow down investment. 
As we recover from the global financial crisis we are faced with the greater imminent danger- the Eco Credit Crisis. The world's fast growing population is using up resources at an unprecedented level, significant part of which is not being renewed and is causing irreparable damage to the environment. If we continue to live on the Earth Ecological credit, by 2030 we need the equivalent of 2 planet resources to keep up our lifestyle.

Hilmy Cader stated "It must be kept in mind that unlike the economic recession, governments cannot bailout enterprises from the emerging credit crisis."

With the world's population expected to shoot to 9 Billion by 2040, it is now up to governments and enterprises around the world to take responsibility-what is being done is certainly not enough (James Leape, 2009)!

One of the real threats to sustainable urbanization is urban poverty. It establishes a sophisticated and intricate system that results in a vicious cycle of poverty where conventional market economics condemns millions to poverty, while awarding a few with prosperity. The World Bank affirms that over 3 billion people live on less than $\$ 2.50$ a day, and with the recent global crisis, this number is bound to grow unprecedentedly.

Twelve Principles of Innovation for BOP Markets ( C.K Prahalad, 2005).

1. Focus on price performance of products and services. Serving BOP markets is not just about lower prices. It is about creating a new priceperformance envelope. Quantum jumps in price performance are required to cater to BOP markets

2. Innovation requires hybrid solutions. BOP consumer problems cannot be solved with old technologies. Most scalable, price-performanceenhancing solutions need advanced and emerging technologies that are creatively blended with the existing and rapidly evolving infrastructures.
3. As BOP markets are large, solutions that are developed must be scalable and transportable across countries, cultures, and languages. How does one take a solution from the southern part of India to the northern part? From Brazil to India or China? Solutions must be designed for ease of adaptation in similar BOP markets. This is a key consideration for gaining scale.

4. The developed markets are accustomed to resource wastage. For example, if the BOP consumers started using as much packaging per capita as the typical American or Japanese consumer, the world could not sustain that level of resource use. All innovations must focus on conserving resources: eliminate, reduce, and recycle. Reducing resource intensity must be a critical principle in produkt development, be it for detergents or ice cream.

5. Product development must start from a deep understanding of functionality, not just form. Marginal changes to products developed for rich customers in the United States, Europe, or Japan will not do. The infrastructure BOP consumers have to live and work in demands a rethinking of the functionality anew. Washing clothes in an outdoor moving stream is different from washing clothes in the controlled conditions of a washing machine that adjusts itself to the level of dirt and for batches of colored and white clothes.

6. Process innovations are just as critical in BOP markets as produkt innovations. In developed markets, the logistics system for accessing potential consumers, selling to them, and servicing products is well-developed. A reliable infrastructure exists and only minor changes might have to be made for specific products. In BOP markets, the presence of a logistics infrastructure cannot be assumed. Often, 
innovation must focus on building a logistics infrastructure, including manufacturing that is sensitive to the prevailing conditions. Accessing potential consumers and educating them can also be a daunting task to the uninitiated.

7. Deskilling work is critical. Most BOP markets are poor in skills. The design of products and services must take into account the skill levels, poor infrastructure, and difficulty of access for service in remote areas.

8. Education of customers on product usage is key. Innovations in educating a semiliterate group on the use of new products can pose interesting challenges. Further, most of the BOP also live in "media dark" zones, meaning they do not have access to radio or TV. In the absence of traditional approaches to education - tradicional advertisingnew and creative approaches, such as video mounted on trucks and traveling low-cost theatrical productions whose job it is to demonstrate product usage in villages, must be developed.

9. Products must work in hostile environments. It is not just noise, dust, unsanitary conditions, and abuse that products must endure. Products must also be developed to accommodate the low quality of the infrastructure, such as electricity (e.g., wide fluctuations in voltage, blackouts, and brownouts) and water (e.g., particulate, bacterial, and viral pollution).

10. Research on interfaces is critical given the nature of the consumer population. The heterogeneity of the consumer base in terms of language, culture, skill level, and prior familiarity with the function or feature is a challenge to the innovation team.

11. Innovations must reach the consumer. Both the highly dispersed rural market and a highly dense urban market at the BOP represent an opportunity to innovate in methods of distribution. Designing methods for accessing the poor at low cost is critical.

12. Paradoxically, the feature and function evolution in BOP markets can be very rapid. Product developers must focus on the broad architecture of the system-the platform-so that new features can be easily incorporated. BOP markets allow (and force) us to challenge existing paradigms. For example, challenging the grid- based supply of electricity as the only available source for providing good-quality, inexpensive energy is possible and necessary in the isolated, poor BOP markets.

Despite the idea of serving the poor profitably being with us for over a decade, little has been done to demonstrate the true calling of the private sector, as the entity of risk takers who utilize existing market opportunities to create wealth. While the skepticism of many in the private sector is based is real, the reality of the BOP latent potential is real too. By dedicating more investments into research and development, forming alliances and partnerships with BOP entrepreneurs the road to unleashing the full potential of the BOP market will be realized in our live time.

The private sector is bound to benefit from serving and working with the BOP populace. The synergy created in the process is what will translate into a research ground where innovations and ideas will be developed tested and implemented before being moved up to other markets and segments of the urban society. The bottom-up approach to the creation and development of solutions to the urban 
challenge will place the private sector on a track of sustainability and offer real benefits to the wider society. The challenges that rapid urbanization present us with makes it imperative that we create working models and framework that will enable the private sector to tap into the reservoir of the whole society, including the BOP to come up with economic solutions to the economic problems that threaten the very fabric of urban living today.

\section{Conclusions and Recommendations}

In the world we live today, businesses and top executives must understand what differentiates their companies from others and must understand the needs of the consumers in their markets. If these two ingredients are understood, a business can develop a strategic plan to create a market niche and develop their customer base to be successful. Development of this information along with the development of the internal business processes can lead to some form of a competitive advantage in the market. The businesses and their representatives are directly responsible for the patterns of purchases (in the long run) of each of their customers. How they (the customers) will react within certain situations is largely due to the education and supplying the customer with enough data and tools to proficiently inform them of what is to be completed and within what context and timeframe. Understanding the customer and their reactions to the environment will prolong the life of the relationship between businesses and their customers.

Our society is facing a financial crisis, an economic crisis, and as recent research is increasingly showing, a humanitarian crisis. Recession has hit the entire world. Wherever we go everybody is talking about it and each and every trade is affected by it. If the recession protracts, more and more people will fail to get out of poverty.

The Bottom of the Pyramid approaches offers the private sector an opportunity to lead the way towards urban economic and social

transformation in the 21stcentury. What is fundamentally required is the elicitation of the adventurous spirit of the sector to push the frontiers of market economics to new heights. The risk-taking attitude of the entrepreneurs of the industrials revolution who opened the wells of wealth to humanity through inventions and innovations needs to be relived in our times.

Getting the right combination of scale, technology, price, sustainability, and usability requires that managers start with a "zero-based" view of innovations

for the BOP markets. Managers need a new philosophy of innovation and product and service delivery for the BOP markets. The 12 principles that constitute the minimum set of a philosophy of innovation are critical to understand and apply. Needless to say, they challenge the existing assumptions about product and market development. By forcing managers in large enterprises to rethink and re-examine their assumptions about form and functionality, about channels and distribution costs, BOP markets can serve as catalysts for new bursts of creativity. The biggest advantage is often in challenging the capital intensity and the managerial cost structures that have been assumed in MNCs.

Innovation in BOP markets can reverse the flow of concepts, ideas, and methods. Therefore, for an MNC that aims to stay ahead of the curve, 
experimenting in BOP markets is increasingly critical. It is no longer an option.

\section{References}

1. Bernhardt and C. Owens, 2009. "Rebuilding a Good Jobs Economy," The Nation, 30 March 2009 edition

2. Auclair C. 2008. How can the Bottom of the Pyramid Approach Work for the Slums? The Habitat Debate, 14 ,

3. Bender, Paul S. 1976 "Design And Operation of Customer Service Systems", American Management Association, New York.

4. Steven M. Bragg, 2006 "Outsourcing: A guide to: selecting the correct business unit, negotiating the contract, maintaining control of the process ", John Wiley \& Sons, Inc., New Jersey

5. C. K. Prahalad and Stuart Hart 2002, 'The Fortune at the Bottom of the Pyramid, Strategy + Business', 26,

6. C.K Prahalad, 2004. 'The Fortune at the Bottom of the Pyramid", Wharton School Publishing,

7. C.K Prahalad and M.S Krishnan, 2008. “The New Age of Innovation”, McGraw- Hill, London

8. Foxall, Gordon 1991. "Consumer Psychology in Behavioural Perspective", Journal of Economic Psychologie , 12, 544-547

9. J. Huezo et al., 2009). "The State of the Dream 2009: The Silent Depression,” United For a Fair Economy,

10. PRLog Press Release 2009, After the Global Financial Crisis... expect more, http://prlog.org/10373858

11. Applied Research Center 2009, Race and Recession, , http://arc.org/downloads/2009_race_recession

12. UN-HABITAT 2007. Business for Sustainable Urbanization, Challenges and Opportunities,

13. World Bank 2009, Weathering the Global Economic Crisis: Lessons for Emerging Markets, http://worldbank.org/DEC/weathering-the-global-economic-crisis

14. United Nations 2009, World Economic Situation and Prospects 2009, http://www.un.org/esa/policy/wess/wesp

15. United for a Fair Economy 2009, State of the dream 2009: The silent Depression, www.faireconomy.org/dream. 